\title{
Extremophiles: photosynthetic systems in a high-altitude saline basin (Altiplano, Chile)
}

\author{
Alejandro Angel · Irma Vila $\cdot$ Venecia Herrera
}

Received: 12 June 2015/ Accepted: 5 January 2016/Published online: 8 March 2016

(C) The Author(s) 2016. This article is published with open access at Springerlink.com

\begin{abstract}
Studies of different hypersaline systems have revealed various types of limitation. We evaluated the phototrophic microbial assemblages over a whole seasonal cycle (wet vs dry) in the Salar de Alconcha, a high-altitude (4250 m altitude) saline basin. Phototrophic microbial communities were obtained from contrasting ecotypes, and examined for the effects of proximity and salinity variations. We also analyzed pigment profiles pointing to photosynthetic activity. While taxonomic diversity was limited to three algal groups (chlorophytes, diatoms, and cyanobacteria) ecological preferences were highly variable. Physical limitations when the photosynthetic system turn drier (maintaining viability and stability) appear to be the most successful adaptation (constrained assemblages) to the extreme condition in the Altiplano. This suggests that phototrophic microorganisms rarely achieve optimal growth, and could only do so when rain events reduce salinity (e.g. austral summer). However, environmental condition over the salt crust (total salt concentration: $119.74 \mathrm{~g}^{-1}$ ) was an important driver to algal biomass. Overall, dominated by Dunaliella salina

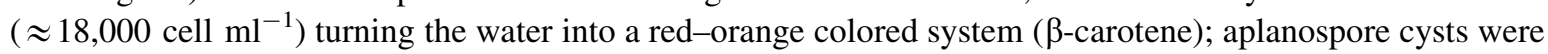
observed only during the driest season (austral winter). Our results suggest specific restrictive environments (e.g. environmental dissimilarity in the physical landscape) for phototrophic microbial colonization in highaltitude saline systems quite dependent upon water availability (system on the edge). The present study is a contribution for a better understanding of both the ecology of extreme environments and polyextremophiles communities (phototrophs) that inhabit them. Active salars are considered to be useful analogs of ancient photosynthetic systems, currently very pressured by groundwater extraction. Thus, altering the volume of water through the basin would have negative consequences on the structure and dynamics of local communities, and also in the stability of ecosystem functions.
\end{abstract}

Keywords Active salars $\cdot$ Aplanospore cysts $\cdot \beta$-Carotene $\cdot$ Chlorophytes $\cdot$ Cyanobacteria $\cdot$ Diatoms . Hypersaline systems

Electronic supplementary material The online version of this article (doi:10.1007/s40071-016-0121-6) contains supplementary material, which is available to authorized users.

\footnotetext{
A. Angel $(\bowtie) \cdot$ V. Herrera

Centro de Investigación de Medio Ambiente (CENIMA), Universidad Arturo Prat, Casilla 121, Iquique, Chile

e-mail: aangel@unap.cl

I. Vila

Departamento de Ciencias Ecológicas, Facultad de Ciencias, Universidad de Chile, Casilla 653, Santiago, Chile
} 


\section{Introduction}

It has been known that microbial communities tend to be the dominant biota in hypersaline environments. Indeed, strongly saline environments are inhabited by specific halophilic species (Oren 2005). Microbial communities from strongly saline environments (salinity range 50-150 $\mathrm{g}^{-1}$ ) have potentially interesting physiology (Oren 2002), and some authors have suggested these systems as relevant models for a better understanding of both the early stages of life on Earth and possible extraterrestrial life (Kunte et al. 2002; Mancinelli et al. 2004). Highly saline wetlands in the Altiplano are inhabited by only few higher organisms such as brine shrimps, crustacean and insects, some lakes support zooplankton communities (e.g. amphipod, copepods, chironomid, ostracod, cladoceran, leech, rotifer, nematode and trichopteran) and surrounding macrophytes (Zúñiga et al. 1991, Scott et al. 2015). The dominant phototrophs are halophilic and halotolerant algae and cyanobacteria as well as anoxygenic phototrophic bacteria (Demergasso et al. 2008; Dorador et al. 2008; Thiel et al. 2010).

Active salars in the Altiplano are considered to be remnants of the extensive paleolakes that once occupied the plains; these aquatic habitats developed since the end of the Pleistocene vary from fresh water systems to lakes and perennial salt lakes with high levels of sodium, sulfates, and chlorides (Vila and Muhlhauser 1987; Risacher et al. 2003). In general, perennial salt lakes and permanent meromictic saline systems tend to have relatively constant salinities over extensive periods of time (e.g. dry season, Oren 2005). On the contrary, temporal and permanent terrestrial wetlands borderline the salt crust can frequently experience fluctuating salinities, water availability, and also can be connected with hypersaline systems during intensive rain events (El Niño-Southern Oscillation ENSO, Risacher et al. 2003). Active salars are truly extreme environments in that resident organisms must deal with not only high salt concentrations, but also dynamic changes in salinity, temperature, and water availability, making these organisms polyextremophiles.

Recent evidence indicates the importance of hypersaline microbial mats to interpreting isotopic biosignal in geological records (Finke et al. 2013). In this aspect, interactions between high-altitude saline systems quite dependent upon water availability and microbial mats formation revealed the presence of unique clusters of Archaea (not previously reported) in the Salar del Huasco (Dorador et al. 2010). Moreover, examinations in the Salar del Huasco suggest that cyanobacterial communities are unique, related to others previously described from the Antarctic, along with others from diverse, but less extreme environments (Dorador et al. 2008). Furthermore, an important novel lineage of Gammaproteobacteria within the community structure indicates the importance of anoxygenic phototrophic communities as primary producers from different systems in the Salar de Atacama (Thiel et al. 2010). These lakes described a high microbial diversity and spatial variability (Demergasso et al. 2004) both in time and space related to the salinity variation (Demergasso et al. 2008). Although aquatic microhabitats occur extensively through the Altiplano, particularly in salars, dynamics of algal communities have not been specifically studied and almost nothing is known about comparison between contrasting conditions (e.g. bofedales vs. salt crust systems).

The Altiplano is considered one of the most extreme environments on the planet (Alpers and Brimhall 1988). Active salars (water available) are characterized by high UV radiation, high heavy metals content, wide daily temperature variation (temperature range -20 to $25{ }^{\circ} \mathrm{C}$, approximately), and aquatic systems with variable salt concentration (Dorador et al. 2008; Demergasso et al. 2008; Risacher et al. 2003). Visually, environmental dissimilarities in the physical landscape into the Salar de Alconcha (4250 m altitude) exhibit the presence of contrasting ecotypes. One area receives inputs of water running along the salt crust between vegetation boundary (Bofedal). On the contrary, over the salt crust a terminal lagoon (Laguna Colorada) very much dependent upon water availability can coexist nearly. Our objectives were to characterize the phototrophic microbial assemblages in the Salar de Alconcha (salt flat area $3.8 \mathrm{~km}^{2}$ ) by analyzing both community dynamics and composition as related to the environmental conditions. The influence factors evaluated between both systems that may explain their behavior are discussed. 


\section{Materials and methods}

Study area

Salar de Aconcha is a (total basin area $120 \mathrm{~km}^{2}$ ) high-altitude ( $4250 \mathrm{~m}$ of altitude) saline basin located in the southern Altiplano (Fig. 1). The region comprises a network of high-altitude salars associated with wetland vegetation (e.g. Bofedales) that may have underlying peat layers (Maldonado 2014), inhabiting in margins of shallow saline systems. Salar de Alconcha is an extreme environment (temperature mean $3.5^{\circ} \mathrm{C}$ ) and exhibits visual dissimilarity between two areas (north and south) with two different systems (total water area $0.75 \mathrm{~km}^{2}$ ) quite dependent upon water availability (no more than $10 \mathrm{~cm}$ of water column); potential evaporation is greater (annual average $1620 \mathrm{~mm}$ ) than precipitation (annual average $200 \mathrm{~mm}$ ), falling mostly during the austral summer and some snow in winter (Risacher et al. 2003). Both systems studied, Bofedal (S $21^{\circ} 03^{\prime} 14^{\prime \prime}$, W $68^{\circ} 29^{\prime} 32^{\prime \prime}$ ) and Laguna Colorada (S $21^{\circ} 03^{\prime} 68^{\prime \prime}$, W $68^{\circ} 29^{\prime} 26^{\prime \prime}$ ), are located approximately $150 \mathrm{~m}$ apart (Fig. 1) and were selected based on proximity and notable environmental dissimilarities (Fig. 2). Laguna Colorada (L) is a terminal lagoon situated over the salt crust (Fig. 2a), lacking any superficial channels approximately $100 \mathrm{~m}$ from the nearest vegetation. On the contrary, the Bofedal (B) is situated in a terrestrial system that borderlines the salt crust and less than $10 \mathrm{~m}$ from the nearest vegetation (Fig. 2b). However, the connection between both systems during intensive rain events is highly possible.

Sample collection and biological analysis

Samples were collected over a whole seasonal cycle (wet vs dry) in 2010, approximately 3-month intervals (January and March: wet season; August and November: dry season). Microbial samples were collected mixing two bottles until complete $10 \mathrm{l}$ in the same spot (samples were taken in the morning after surface ice was melted) and filtered in situ with $20 \mu \mathrm{m}$ mesh, then fixed with lugol-acetic solution (Parsons et al. 1984). Likewise, other two unfiltered bottles were taken for smaller cells evaluation; these samples were filtered (sample volume $100 \mathrm{ml}$ ) with an equipment to concentrate phytoplankton on polycarbonate membrane (pore size $5 \mu \mathrm{m}$, Fournier 1978). The filters were deposited in sedimentation chambers for $24 \mathrm{~h}$. Abundance values
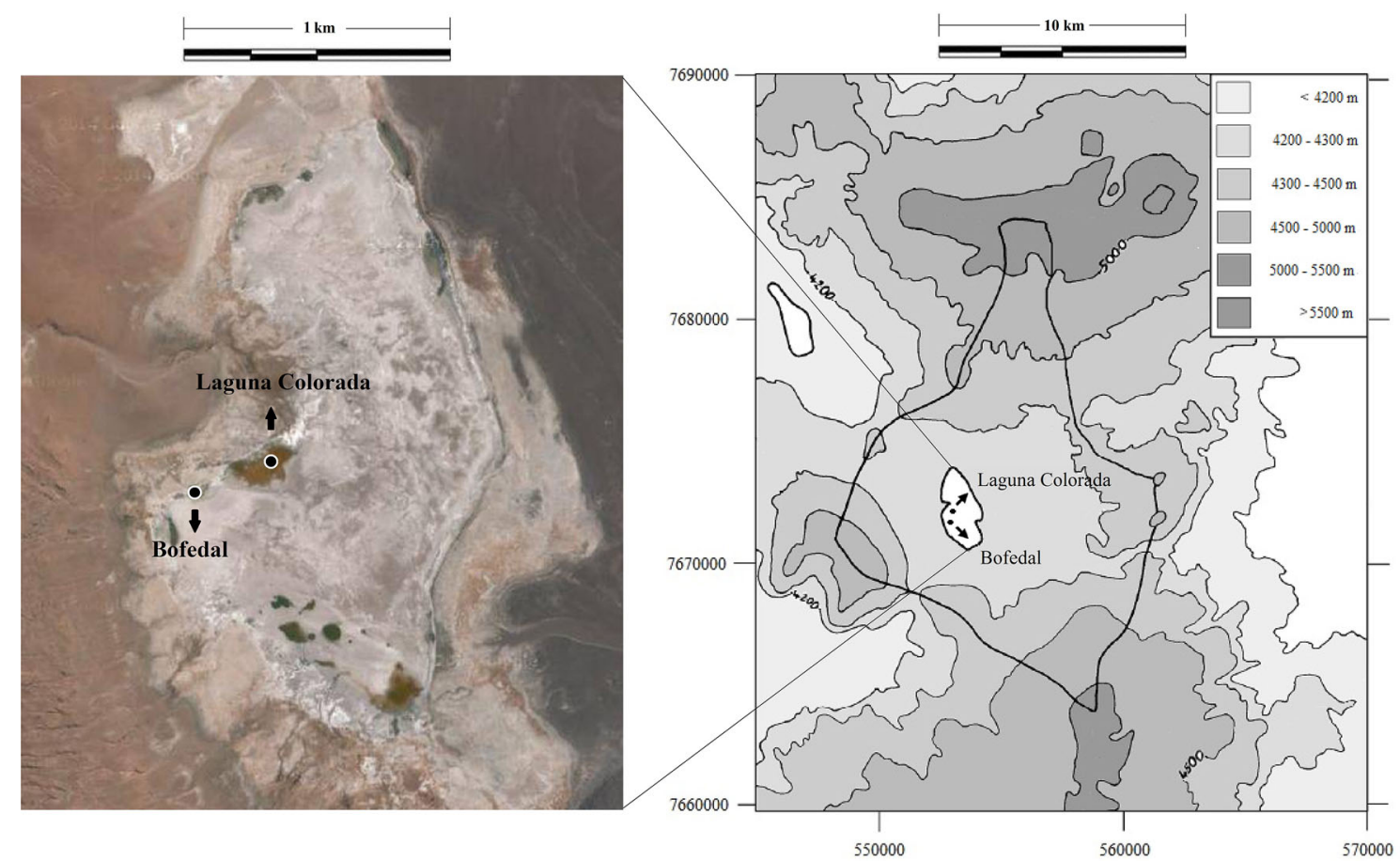

Fig. 1 Geographic location of the two permanent wetlands studied in the Salar de Alconcha, Northern Chile. Solid circles represent sites studied 

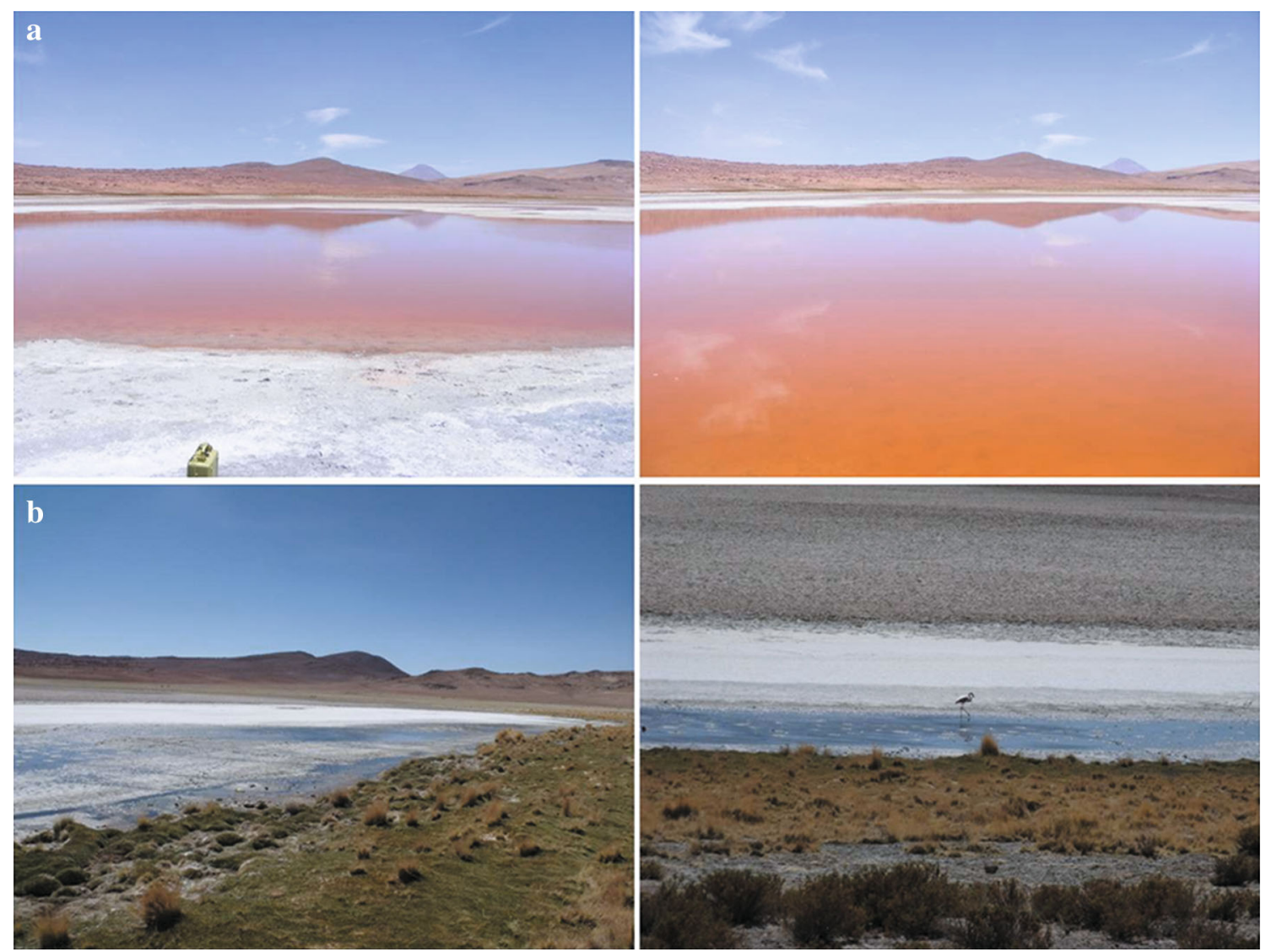

Fig. 2 Habitat description. a Laguna Colorada, salt crust system with intensive red-orange water can be observed; b Bofedal, inflow waters running along the salt crust and borderline a vegetation boundary (Bofedales); associated biota (Flamingos) can be observed

and taxonomic identification were analyzed after sedimentation following the Utermöhl method (1958). The phototrophic microbial species were identified and their abundance estimated with an inverted microscope (Olympus CK-2) at $1000 \times$ and $400 \times$ magnification. Each cell was counted as an individual. For colonyforming species, each colony was also counted as an individual. Microbial concentration (cells $\mathrm{ml}^{-1}$ ) was expressed in Table 2 as the total percentage in relation with the total abundance for each station. Predominance and frequency were calculated using the procedure described by Bodenheimer (1955) in Avendaño and Saíz (1977). Ecological indices (dominance, Shannon diversity and equitability) were calculated using procedures described by Harper (1999). Taxonomic identification was based on species and keys described in Teodoresco (1905), Simonsen (1987), Lange and Mary Ann (2002), Cadima et al. (2005) and Diaz and Maidana (2005).

Chemical analysis and HPLC chromatography

All the samples ( 11 bottle per each sample) were kept cold until return to the laboratory. Analyses of $\mathrm{B}, \mathrm{NO}_{2}{ }^{-}$, $\mathrm{NO}_{3}{ }^{-}$and $\mathrm{PO}_{4}{ }^{3-}$ were performed using absorption spectrophotometer (APHA 2005). The elements $\mathrm{Cu}, \mathrm{Fe}$, $\mathrm{Mn}$ and $\mathrm{Mg}$ were quantified by atomic absorption spectrophotometer FAAS. Measurements were made in duplicate for each analysis. Pigment profiles were estimated using homogeneous suspensions of $4 \mathrm{ml}$ taken from each sample after thorough mixing. Cells were centrifuged at $5000 \mathrm{rpm}$ for $5 \mathrm{~min}$ and the washed cell pellet was mixed with $4 \mathrm{ml}$ of acetone/water $(80: 20, \mathrm{v} / \mathrm{v})$. The mixture was left for $10 \mathrm{~min}$ at room temperature to ensure complete extraction. The extract was centrifuged for $5 \mathrm{~min}$ at $5000 \mathrm{rpm}$ and the colourless biomass was discarded (Jin et al. 2003). Pigment profiles were obtained by separation with HPLC chromatography (Shimadzu LC-10AV) provided with a Shimadzu SPD 10-AV UV-visible detector, using a 


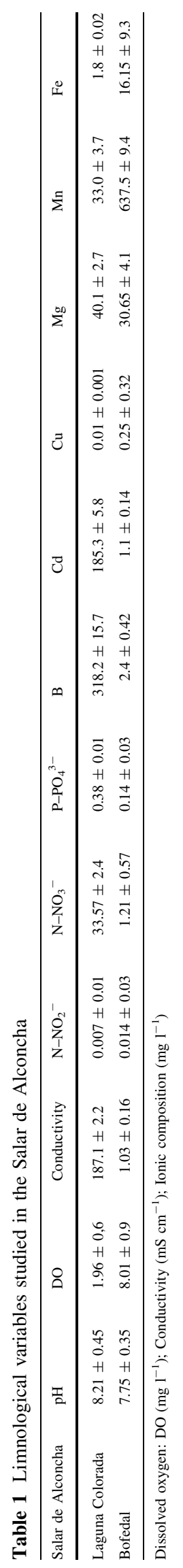




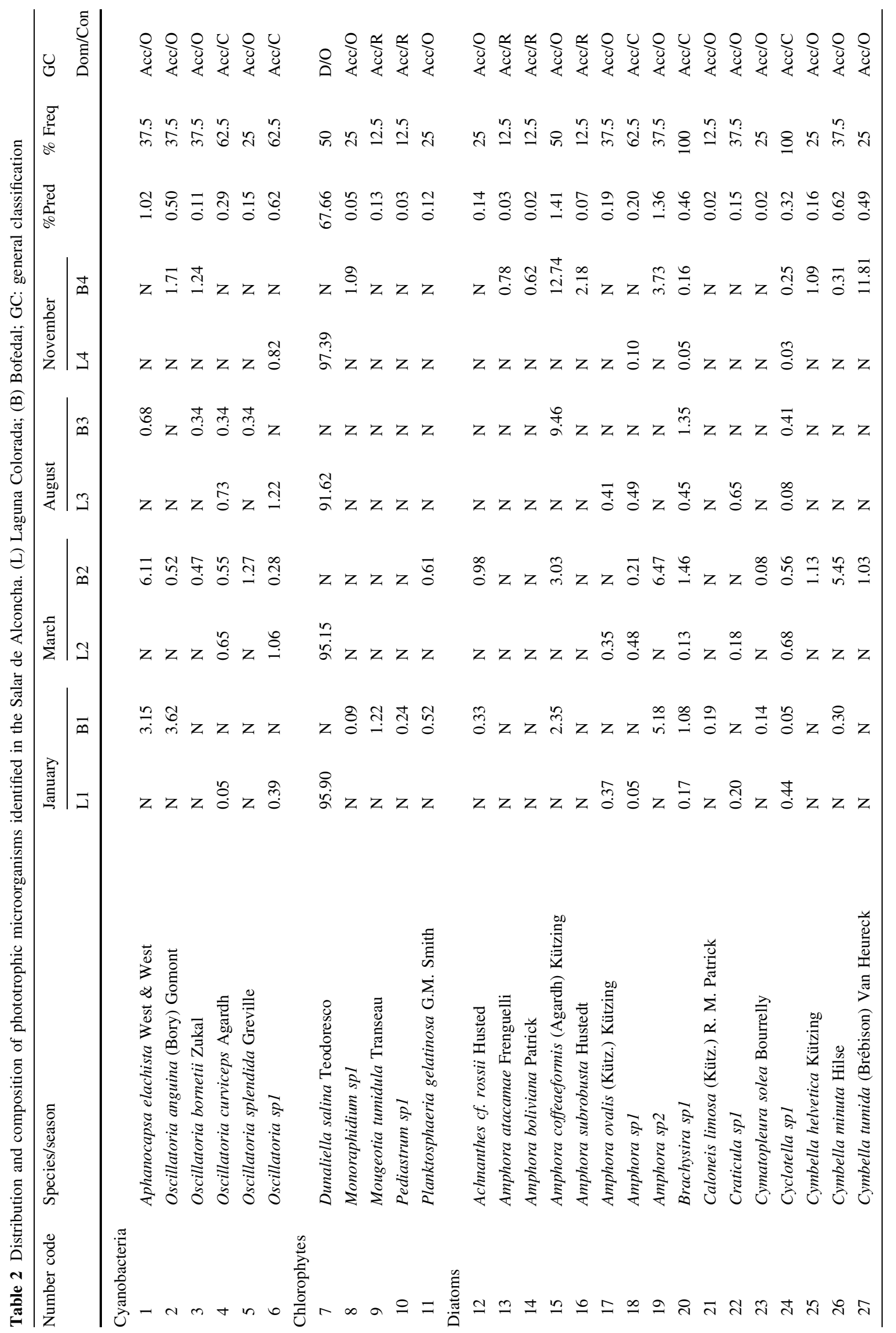




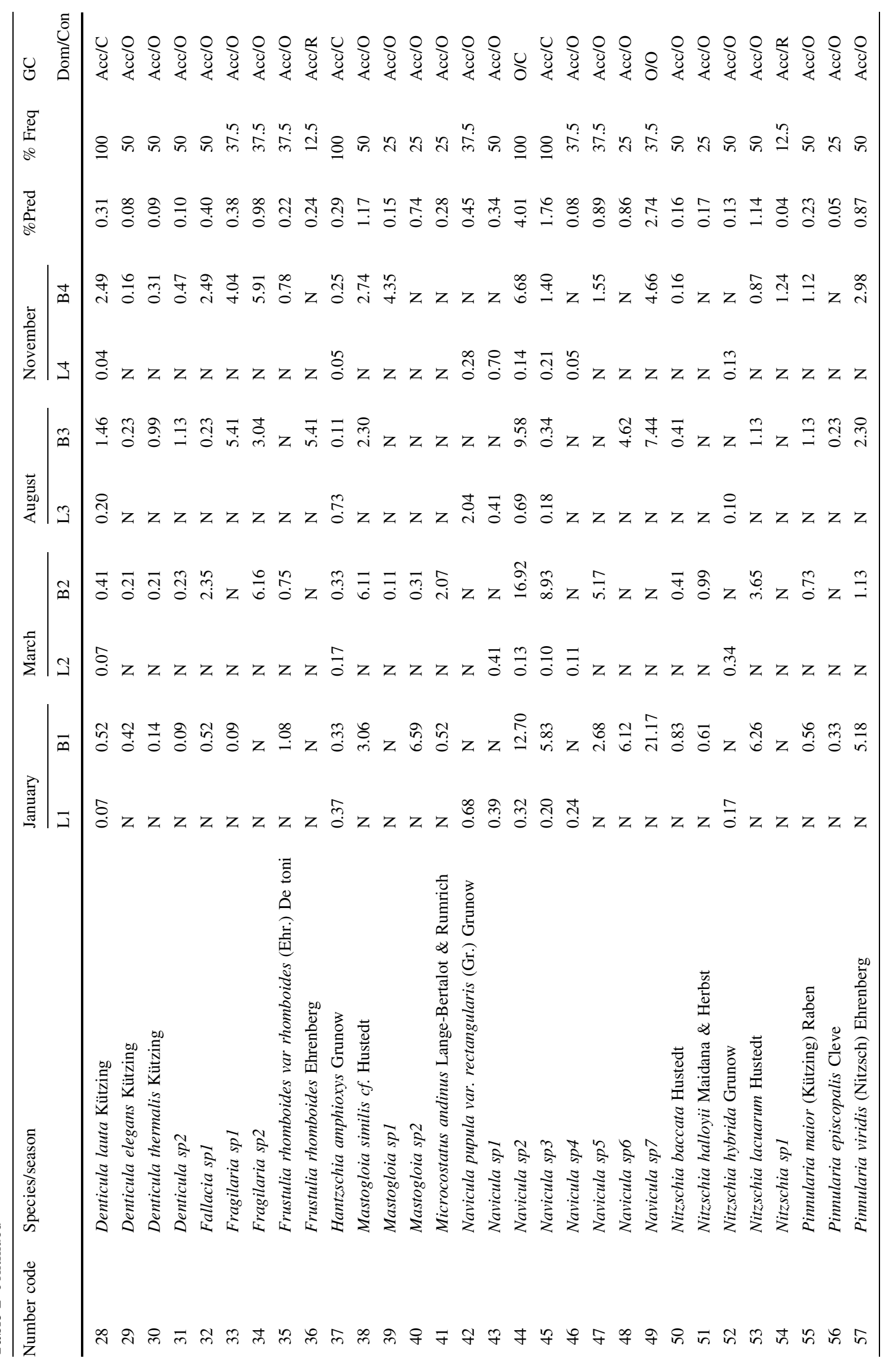




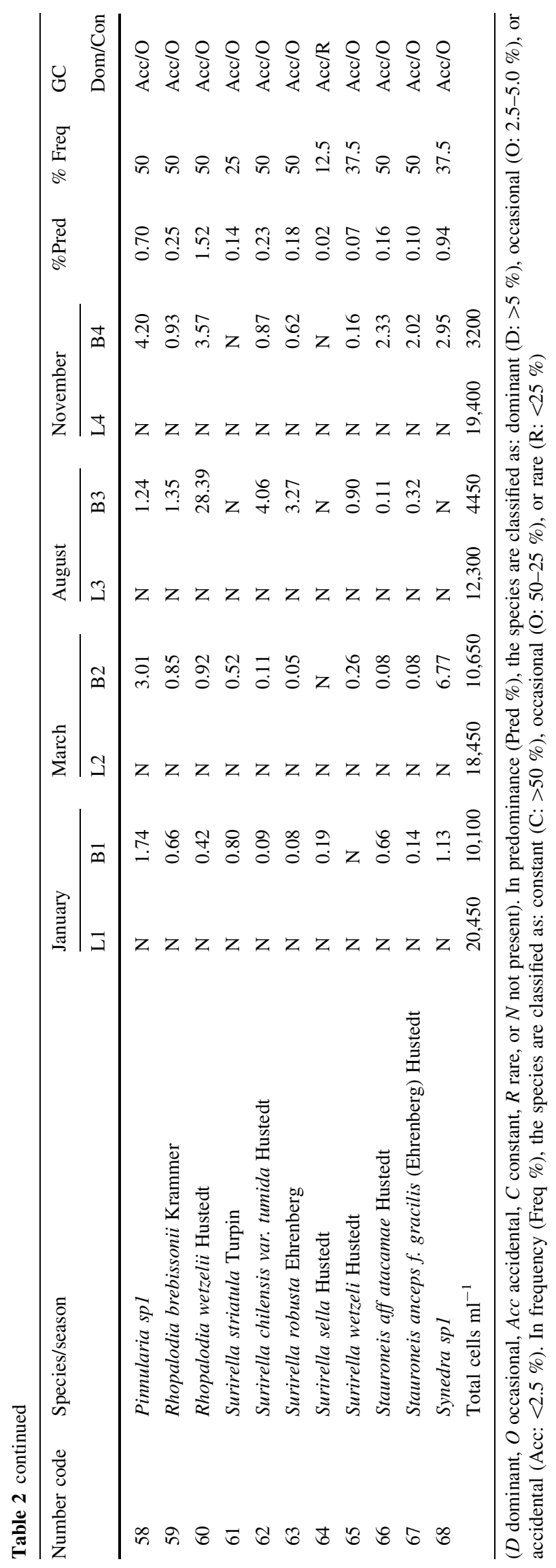


LichroCart RP-18 $(5 \mu \mathrm{m})$ column of $250 \times 4 \mathrm{~mm}$. These profiles were lutein, $\beta$-carotene, chlorophyll-a, chlorophyll-b, lycopene, astaxanthin, and zeaxanthin. The detection of $\beta$-carotene was adjusted to $454 \mathrm{~nm}$ (standards of DHI Water and Environment).

\section{Statistical analysis}

Datasets were analyzed with CANOCO software (ter Braak 1988). A preliminary Detrended Correspondence Analysis DCA (following recommendations by ter Braak and Šmilauer 1998) indicated a unimodal response of species variance with $\log$ transformation data. DCAs were used to evaluate affinities and differences between species and stations to avoid the arc-shaped distribution when there is a single strong gradient affecting the samples (Gauch 1982). On the contrary, Nonmetric multidimensional scaling (MDS) was applied to ordinate samples in three dimensions according to their distances. The number of three dimensions was chosen to keep the stress value for dimensional downscaling below the recommended threshold of 0.1 for an ideal preservation of the original distances between samples (Clarke 1993).

\section{Results}

\section{Limnological features}

Despite the fact that the Salar de Alconcha is a high-altitude extreme environment still support a rich number of well-adapted species. According to the nature of the habitat the Bofedal (B) and Laguna Colorada (L) clearly differ from each other (Table 1). Environmental dissimilarity in the physical landscape defines specific limnological conditions (e.g. salinity range, physical condition of water availability and phototrophic microbial composition). Although both habitats in the Salar de Alconcha endured these fluctuating environmental
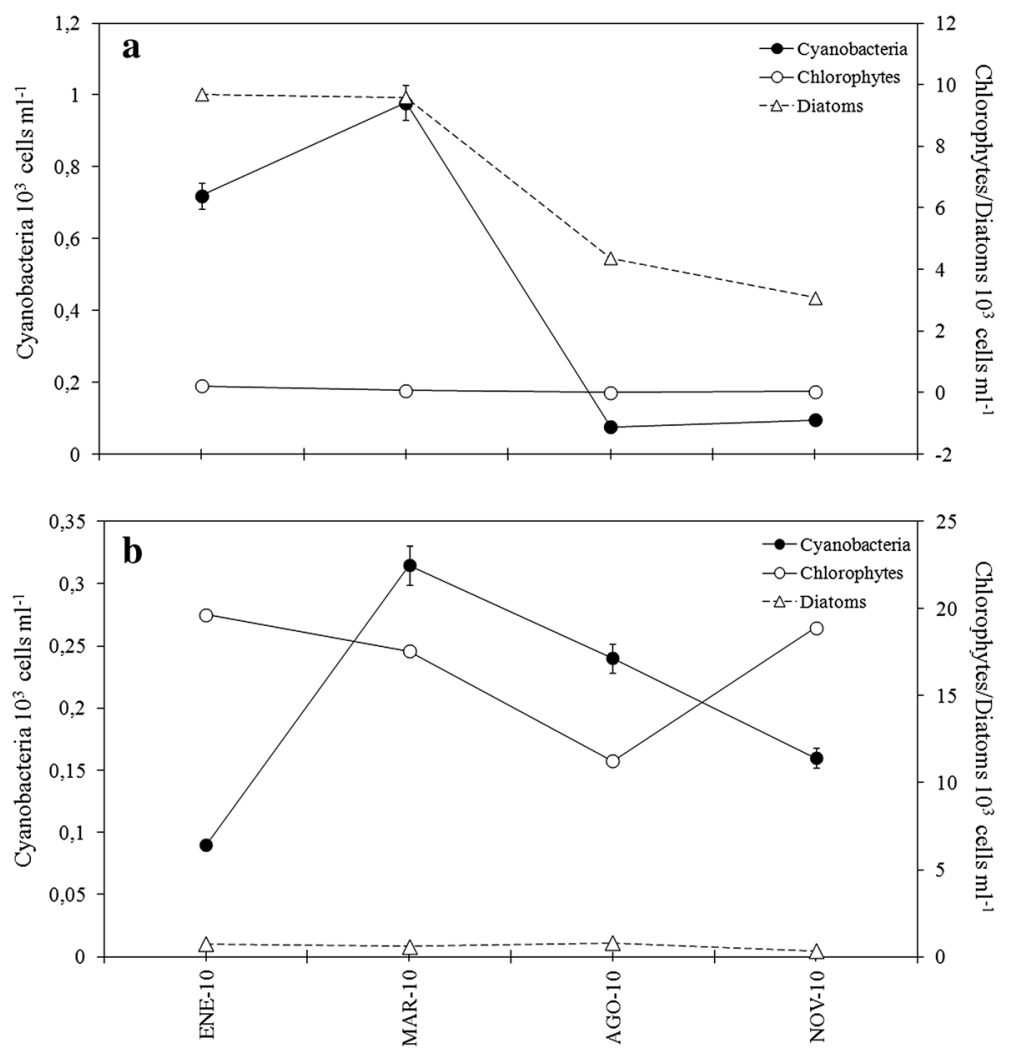

Fig. 3 Time course of division groups (chlorophytes, cyanobacteria, and diatoms) in the Salar de Alconcha. a Bofedales; b Laguna Colorada 
conditions, microbial assemblages (phototrophs) in Laguna Colorada (L) were more stable to the effects of seasonal changes than the Bofedal (B). Limnological conditions clearly differ among both systems studied especially in conductivity, ionic composition and dissolved oxygen (Table 1). Laguna Colorada (L) reported an extreme hypersaline condition (total salt concentration: $119.74 \mathrm{~g}^{-1}$ ) whereas salinity condition in the Bofedal (B) was clearly lower (total salt concentration: $0.51 \mathrm{~g}^{-1}$ ). These environmental conditions result in less restrictive environments for phototrophic microbial colonization in the Bofedal (although resident time was highly variable and decline abruptly in dry seasons) than Laguna Colorada (Table 2).

Community structures, biological factors and dynamics

While diversity was limited to three taxonomic groups (chlorophytes, diatoms, and cyanobacteria), the ecological preferences were quite variable. Three divisions were identified with 30 genera and 68 species; Cyanophyceae (6 species), Bacilliariophyceae (57 species), and Chlorophyceae (5 species). Marked shift were report among these groups both in time and space as consequences of fluctuating environmental condition (Fig. 3). As could be expected, the great number of genera and species in the Bofedal $\left(\mathrm{H}^{\prime}: 2.98 \pm 0.24\right)$ compared with Laguna Colorada $\left(\mathrm{H}^{\prime}: 0.31 \pm 0.13\right)$, which indicates less restrictive environment for colonization here (phototrophs), is an example of natural reservoir for diversity (phototrophs) within the basin. In general, the highest peak in abundance and diversity were reported in wet season (diatoms: $10,300 \pm 180 \mathrm{cells} \mathrm{ml}^{-1}$; cyanobacteria: $1250 \pm 110 \mathrm{cells} \mathrm{ml}^{-1}$; green algae: $18,750 \pm 1600 \mathrm{cells} \mathrm{ml}^{-1}$ ), and decline when the environmental conditions turn drier (diatoms: $8550 \pm 1250 \mathrm{cells} \mathrm{ml}^{-1}$; cyanobacteria: $625 \pm 5$ cells ml$^{-1}$; green algae: $15,100 \pm 5450$ cells ml$^{-1}$ ). Seasonal changes were also reflected in assemblages composition mainly dominated by permanent residents although ecological preferences were
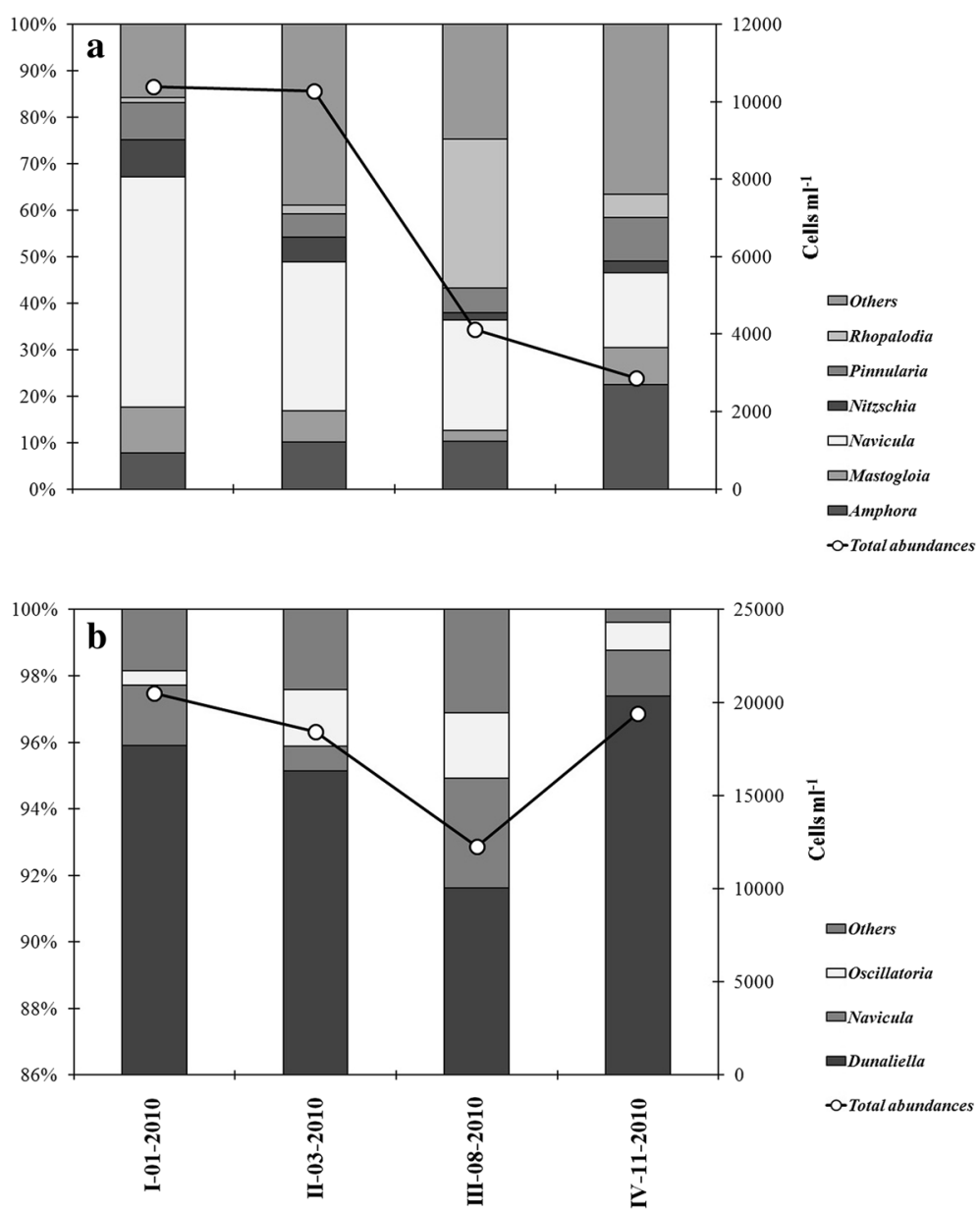

Fig. 4 Relative (percentage) and absolute abundances of the main genera in both systems studied. a Bofedal; b Laguna Colorada 
quite variable. Diatoms were positively correlated with poor-water salinity concentration whereas chlorophytes were negatively correlated to these conditions (Fig. 5). The most dominant groups in the Bofedal (B) were diatoms and cyanobacteria especially in wet season (Fig. 3a). Laguna Colorada (L) was clearly dominated by green algae Dunaliella salina (Fig. 3b). The most diverse group in both systems were diatoms (pennate and lesser centric) followed by large filamentous cyanobacteria (500-2000 $\mu \mathrm{m}$ ), and unicellular green algae (Table 2).

In the Bofedal, a total of 57 species and 25 genera were identified; the most abundant genera were Navicula, Amphora, Rhopalodia, Nitzschia, Pinnularia, and Mastogloia (Fig. 4a). In this aspect, Navicula was the most dominant genus (33.3\% total abundance) with five species very sensitive to seasonal changes (Table 2). Microbial biomass (phototrophs) was highest when the system receive precipitations

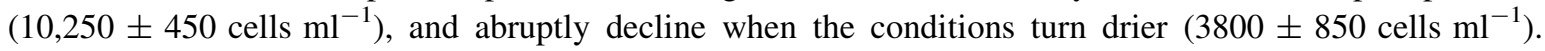
However, Laguna Colorada (L) was more stable and significantly more restrictive for species composition than the Bofedal (B) with a total of 16 species and 10 genera (Table 2). The most abundant genera in Laguna Colorada were Dunaliella, Navicula, and Oscillatoria (Fig. 4b). Although, abundance values were not statistically different $(p=0.11)$ maximum rates were influenced by seasonal rains $\left(19,500 \pm 1450 \mathrm{cells}^{-1}\right)$. These values were considerably influenced by algal biomass of Dunaliella salina (95.4\% total abundance) only associated with few accidental species (Table 2). This condition resulted in less equitability $(0.11 \pm 0.047)$ and high dominance $(0.90 \pm 0.046)$. On the contrary, the Bofedal reported high equitability $(0.78 \pm 0.050)$ and lower dominance $(0.082 \pm 0.027)$.

Results from DCA analysis for coverage values and stations are represented in Fig. 5. All the samples were distributed along the plane defined by the two first axes. Axes I and II account for $72.8 \%$ of total variance from the data set (57.6 and $15.2 \%$ for axes I and II, respectively). Comparative analysis revealed specific ecological preferences. On the first axis, samples dominated by Dunaliella salina were situated nearly to the ordination axis and were opposed to samples dominated by pennate diatoms and large filamentous cyanobacteria, with the exception of two species Oscillatoria curviceps and Oscillatoria sp1. Laguna Colorada (L) was associated separately from the Bofedal (B), which also formed two different groups (wet and dry seasons). With respect to distribution DCA analysis formed two different groups with Dunaliella salina and others 15 accidental species limited to Laguna Colorada (L). Additional supplementary variables represented by three divisions were summarized by Chlorophyceae associated to Laguna Colorada (L) due to higher algal biomass of Dunaliella salina. On the contrary, diatoms and filamentous cyanobacteria resulted in preferences of Bacilliariophyceae and Cyanophyceae (included as supplementary variable in the DCA analysis) to the Bofedal (B). Additionally, distribution of species and stations resulting from the analysis of non-metric multidimensional scaling (MDS) with constrained ellipse $95 \%$ species level using Bray Curtis Index (Fig. 6) was running to contrast the information with DCA analysis. The non-metric MDS distribution for stations was similar to DCA analysis (Fig. 6a), and indicates that phototrophic microbial communities

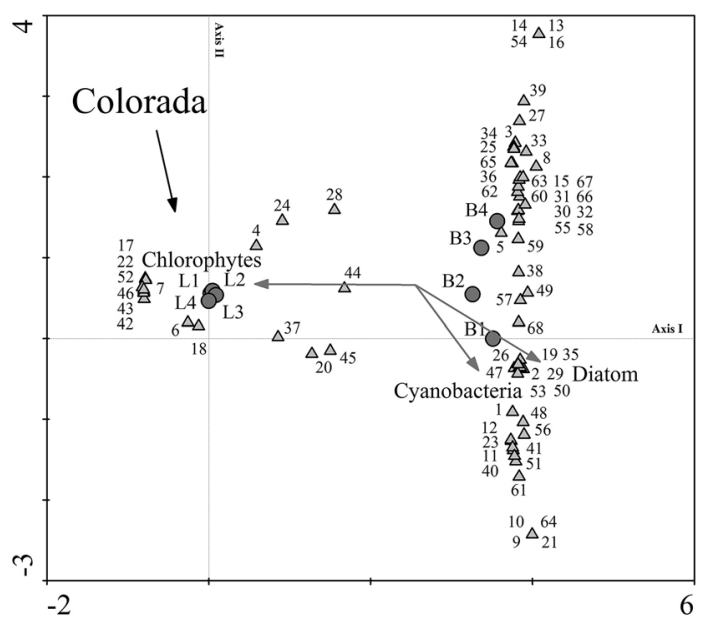

Fig. 5 Detrended correspondence analysis (DCA) based in samples and species data (L: Laguna Colorada; B: Bofedal). Symbols in upper panel (triangle: species; circle: samples). Solid arrows indicate displacement of division groups (chlorophytes, cyanobacteria, and diatom). Numbers correspond to species code described in Table 2 

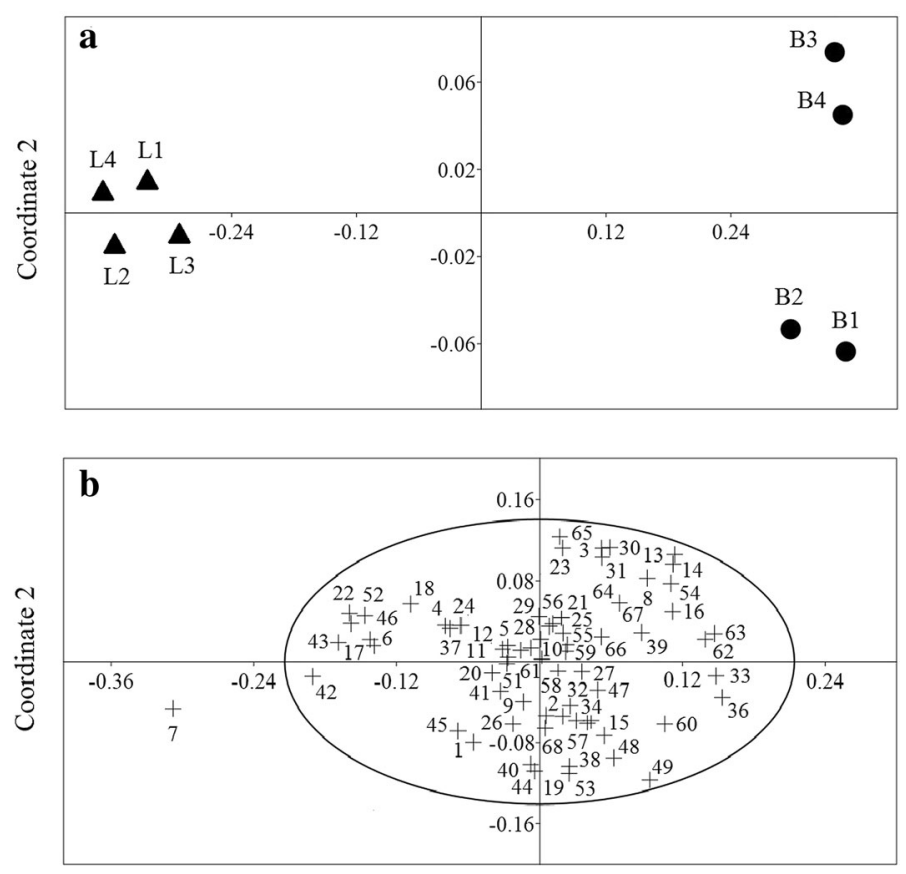

Coordinate 1

Fig. 6 Non-metric (MDS) plot based on seasonal abundance data from Laguna Colorada (triangle) and the Bofedal (circle) in the Salar de Alconcha. Ordination was based on the Bray-Curtis coefficient (a) samples (b) species. The stress value for dimensional downscaling was 0.06 (a) and 0.18 (b), respectively. In the first plots (a), data points from Laguna Colorada (L) and the Bofedal (B) are separated by both dimension axes. This indicates that phototrophic microbial communities of the two sampling locations clearly differed from each other as well as D. salina was situated far away from the total species (ellipse group) identified in both systems. Numbers in figure b correspond to species code described in Table 2

from both systems clearly differ from each other. Marked shift among Dunaliella salina and the entire community structure (including both systems studied) was clearly expressed in the MDS analysis resulting far away from the species into the ellipse (Fig. 6b). Some light microscopy photographs of the most important species found in both systems are shown in Fig. 7.

Life stages of Dunaliella salina and HPLC chromatography

Seasonal stress and salinity variations lead to a series of changes in pigmentation, morphology, and abundance of Dunaliella salina in Laguna Colorada (Fig. 8). While most of the cells were red (Fig. 8a) with elongated ovoid shapes (characteristic of red cells) in wet season (austral summer), round non-motile cells (aplanospore cysts) were observed only during the driest season in austral winter (Fig. 8b). Algal biomass increased considerably in November (austral spring) with most of the cells olive and green-olive (Fig. 8c). Pigment profiles by HPLC chromatography only reported $\beta$-carotene overcome the limit detection without sample concentration (Fig. 9); negative results for other pigments in concentrated samples over the limit detection corroborated the dominant concentration of $\beta$-carotene within the system.

\section{Discussion}

Extreme photosynthetic communities

Phototrophic microbial communities do not have a significant association with chemical and physical variables in high-altitude wetlands, probably because species ensembles have renovation cycles longer than one year (Márquez-García et al. 2009). However, specific analysis in each ecosystem is necessary to understand this aspect, mainly due to high spatial and temporal heterogeneity as well as influences of complex 


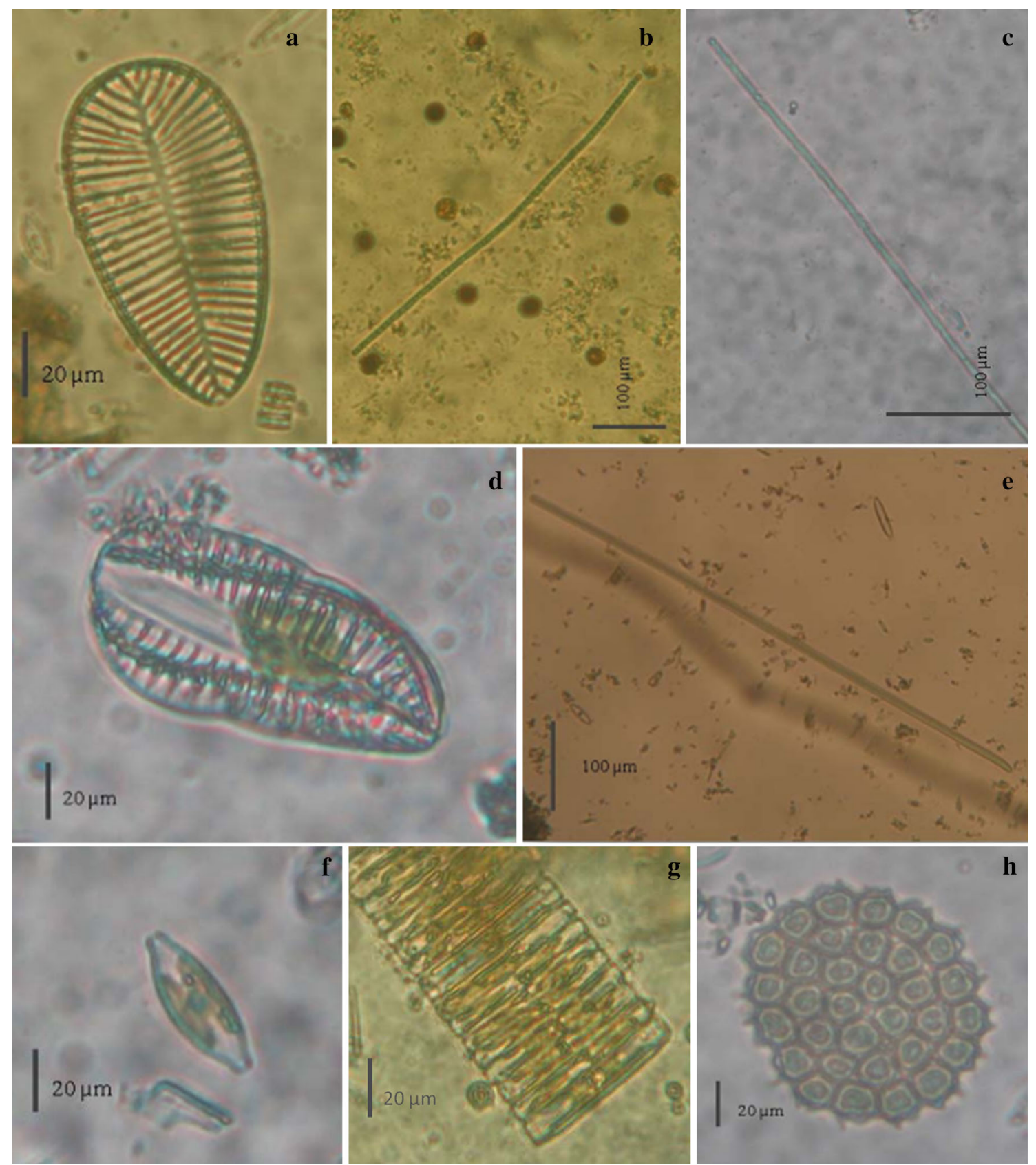

Fig. 7 Photographs of different species observed by light microscopy. Panel correspond to a Surirella wetzeli (Bofedal); b Oscillatoria sp., and Aplanospore cells (Dunaliella salina, Laguna Colorada); c Oscillatoria splendida (Bofedal); d Rhopalodia wetzelii (Bofedal); e Oscillatoria curviceps (Laguna Colorada); f Stauroneis anceps $f$. gracilis (Bofedal); g Fragilaria sp. (Bofedal); h Pediastrum sp. (Bofedal)

environmental factors. Photosynthetic microbial communities described in the Salar de Alconcha differ from other large high-altitude lakes with lower salinity such as the Lago Chungará (Dorador et al. 2003). Environmental dissimilarity in the physical landscape defines specific environments for phototrophic microbial assemblages. Several species identified in the Salar de Alconcha has been described as benthonic and typical of hypersaline, mesohaline, or brackish systems, such as Dunaliella salina (Fig. 10a), Rhopalodia wetzelii, and Hantzschia amphyoxis (Fig. 10b), respectively (Cadima et al. 2005).

An interesting association between Bofedales (B) and some phototrophs groups (e.g. diatoms or large filamentous cyanobacteria) seems to evidence an important linkage into the ecosystem function. The persistence and survival of diatoms species (e.g. species inhabiting nitrogen-poor systems) and large filamentous 

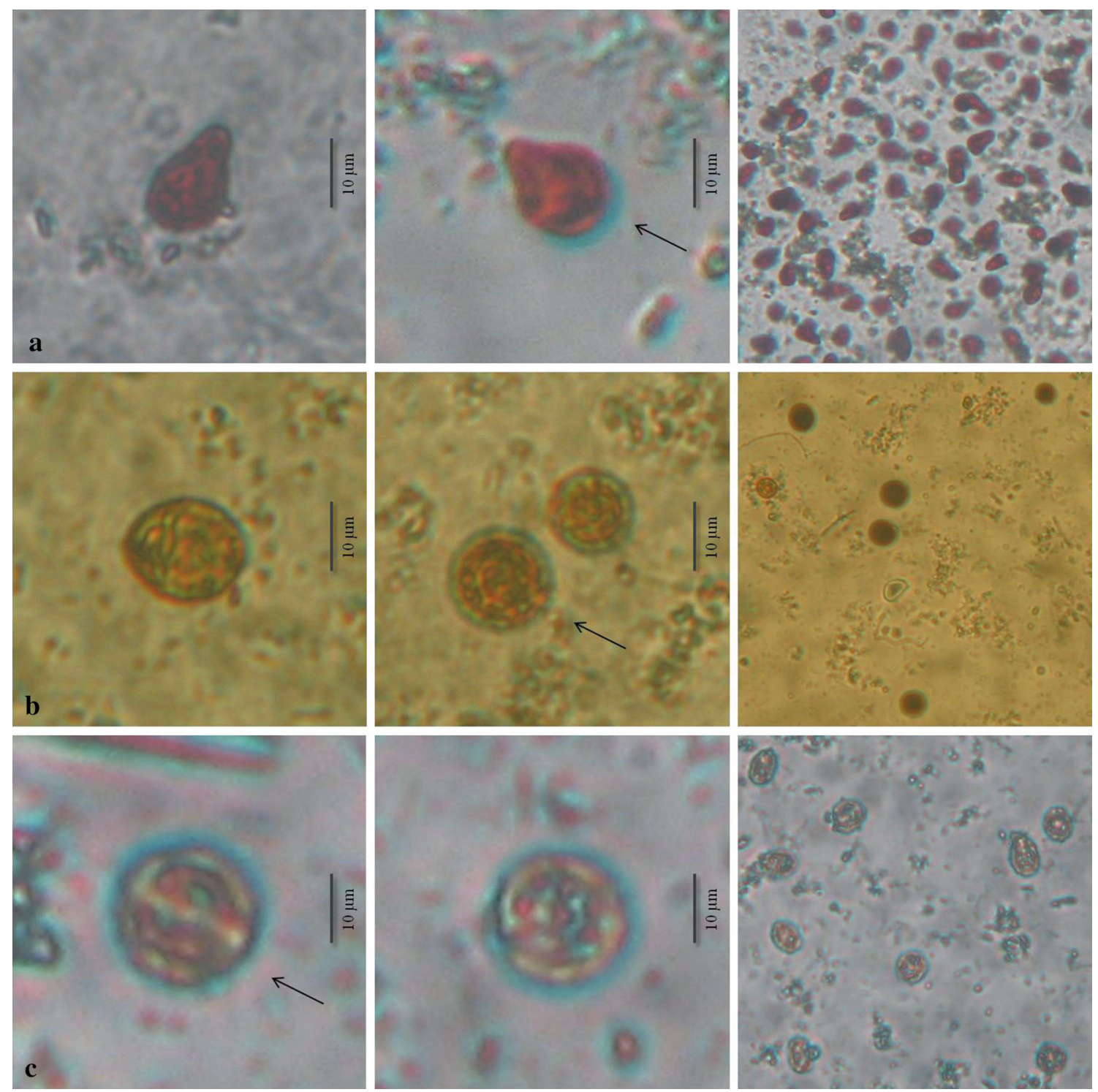

Fig. 8 Light microscopy examination of Dunaliella salina (Laguna Colorada) in different seasons. a January, indicating intense red pigmentation; b August, indicating aplanospores with thick cells wall; $\mathbf{c}$ November, indicating cell division and olive-green pigmentation

cyanobacteria (sizes from 700 to $2000 \mu \mathrm{m}$ ) under natural conditions seem to depend on a variety of physical factors provided by the Bofedal (e.g. temperature balance (reduce daily amplitude in surface water), soil quality or water retention). Some of these species [e.g. Oscillatoria anguina, Oscillatoria bornetii, and Oscillatoria splendida (Fig. 7c)] were strongly restricted to these conditions whereas others two large filamentous cyanobacteria [Oscillatoria curviceps (Fig. 7e) and Oscillatoria spl (Fig. 7b)] were also distributed over the salt crust (Laguna Colorada). Distribution of cyanobacteria in the Altiplano describes the presence of Oscillatoriales, Pleurocapsales, Chroococcales, and Nostocales in the Salar del Huasco (Dorador et al. 2008). Furthermore, cyanobacteria also describe the presence of unique stratified photosynthetic microbial mats (e.g. Oscillatoriales, Synechococcus, Cyanothece and Gloeocapsa groups and genus Gloeobacter) in the salar de Llamara, a salt flat basin (Salar de Llamara) located in the Atacama desert (Demergasso et al. 2003). Additionally, photosynthetic pigments were detected being more diverse on the upper photosynthetic layer associated to evaporites domes of gypsum in the Salar de Llamara, where cyanobacteria and diatoms species were also detected (Rasuk et al. 2014). However, there is little information about cyanobacterial communities under hypersaline condition (Dorador et al. 2008). Our results describe the presence of two filamentous 


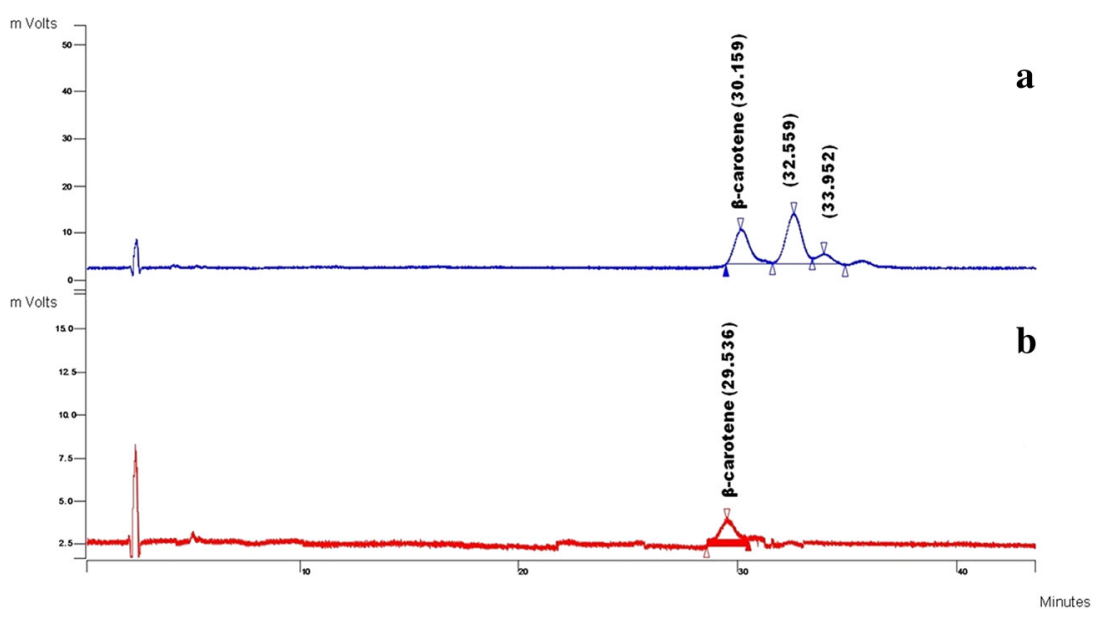

Fig. 9 Chromatographic analysis by HPLC in microbial extracts. a chromatographic profile of Laguna Colorada; b chromatographic profile of $\beta$-carotene standard
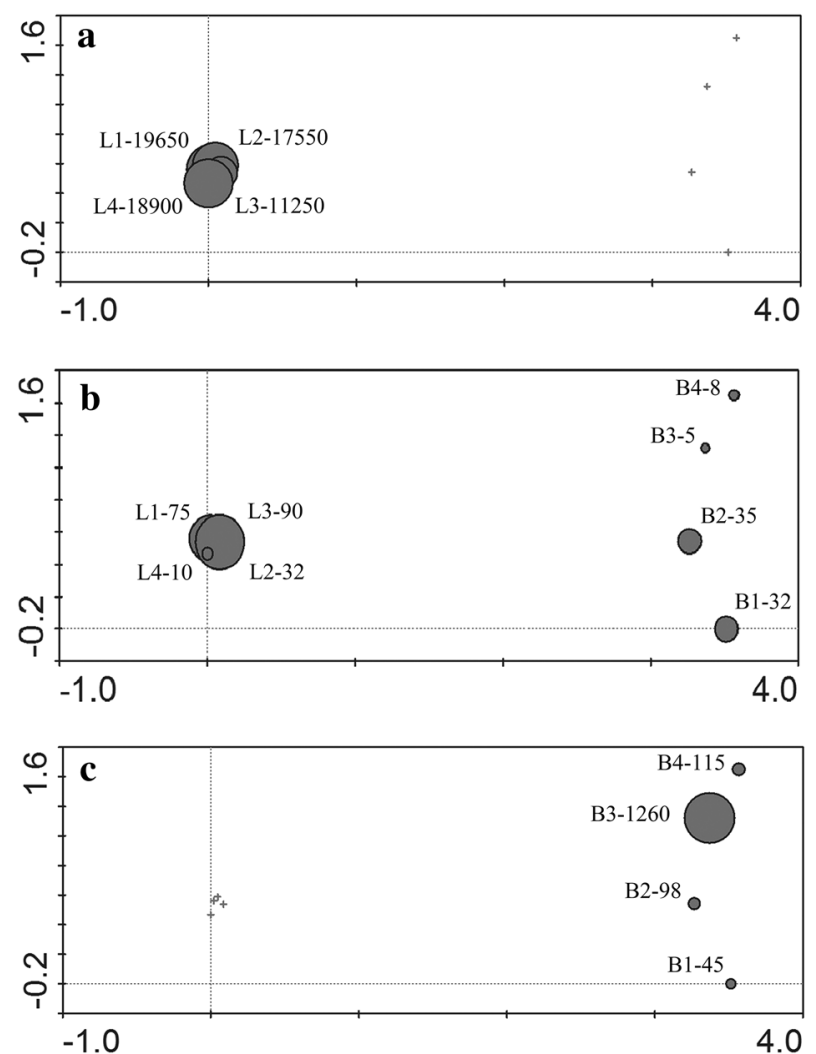

Fig. 10 Plots of the main species based on DCA analysis in the Salar de Alconcha. (L) Laguna Colorada; (B) Bofedal. Numbers indicate absolute abundance in cells $\mathrm{ml}^{-1}$. a Dunaliella salina; b Hantzschia amphioxys; c Rhopalodia wetzelii

cyanobacteria surviving under extreme hypersaline condition (total salt concentration: $119.74 \mathrm{~g}^{-1}$; conductivity: $187.1 \pm 2.2 \mathrm{mS} \mathrm{cm}^{-1}$ ). Several species found in the Salar de Alconcha represent unique examples to observe in situ the seasonal adaptation to a wide-range of environmental condition. For example, Hantzschia amphyoxis are common inhabitant of shallow ecosystems, slightly brackish habitats including Antarctic saline lakes, or even saline soils (Germain 1981; Margalef 1983; Sabbe et al. 2002). Furthermore, Rhopalodia wetzelii (Fig. 7d) was a very sensitive species to the seasonal changes (Fig. 10c); probably because this species has an important role in saline, mesohaline, or brackish systems (e.g. Bofedales). This species has been 
described in several systems in the Altiplano (Eastern cordillera and alluvial plains in Bolivia), classified as euryhalobous, mainly benthic or epiphyte (Cadima et al. 2005). An interesting strategy of this species is the association with a cyanobacterial endosymbiont, which allows it to grow into nitrogen poor ecosystems; such as the condition described for species associated to the Bofedal (B) in the Salar de Alconcha.

\section{Physical limitations and Dunaliella species}

Dunaliella has been described as the main or the only primary producer in diverse hypersaline ecosystems worldwide, although it is quite surprising that only few quantitative studies have been published on the dynamics of Dunaliella populations in natural hypersaline environments (Oren 2005). In this part of the world Dunaliella has been poorly studied; only Dunaliella viridis has been described in some places of South America (Massyuk 1973; Ginzburg 1987). More recently new reports described new species in Chile (Azúa-Bustos et al. 2010; Demergasso et al. 2008). In the Atacama Desert a sub-aerial species of Dunaliella using the condensation of water on spider webs in the walls of a coastal cave could be illustrate one of the first strategies in land colonization by plants (Azúa-Bustos et al. 2010). Moreover, sequences related to Dunaliella salina into the Lake Tebenquiche in the Salar de Atacama (Demergasso et al. 2008) represent a clear evidence of Dunaliella distribution in the Altiplano. Additionally, Iltis et al. (1984) described in the Bolivian Altiplano a species inhabiting a homonymous hypersaline large lake (Laguna Colorada) located in Sud Lípez Potosí. Environmental conditions in this lake promote high algal biomass of Dunaliella sp. turning the water into a red-orange colored system. These large salars (Uyuni and Coipasa) have a close relation with chemical and physical conditions described in the Salar de Alconcha. Similar conditions were reported in Laguna Colorada (L) especially in total salt concentration (total salt concentration: $119.74 \mathrm{~g}^{-1}$ ) characteristic of terminal hypersaline systems with high nutrients concentration (Nitrogen and Phosphorous) and close to anaerobic condition (Oren 2005).

Several treatments have demonstrated that Dunaliella is capable of accumulating $\beta$-carotene and glycerol under conditions of high irradiance and other saline stress conditions (Arun and Singh 2012). Highly photosynthetic systems in the Altiplano represent exceptional conditions for these aspects such as salinity variations and high UV irradiance especially in aquatic systems over the salt crust (sunlight screen reflector). Intensive pigmentation and dynamic responses (e.g. aplanospore cysts formation) of Dunaliella salina to the seasonal changes is a clear example of well adapted species to these conditions. Moreover, some Dunaliella species not only reproduce by division of vegetative cells but show sexual reproduction as well (Oren 2005). One of the most interesting adaptations in Dunaliella species is the formation of vegetative cysts (Hamburger 1905; Margulis et al. 1980; Borowitzka and Huisman 1993; Oren 2005) during winter conditions of short and cold days (Borowitzka and Huisman 1993). These formations (aplanospore cysts) generate great resistance to long periods of dryness, with two extremely resistant thick coats which form a rough cell wall (Leonardi and Cáceres 1997); germinations process occurs in shallow sediments that had become exposed to diluted waters (Oren and Ben-Yosef 1997). This behavior has not been described yet in the Altiplano. Interestingly, our results reported aplanospore formations only during the driest season in winter condition (Fig. 8b), and germination process in the austral spring when the systems could receive intermittent rains events (Fig. 8c). Furthermore, our result in Laguna Colorada detected cadmium concentrations (Table 1) over the tolerance limit described for toxic levels (plants tolerance) in nature (Dong et al. 2007).

\section{Conclusion and perspectives}

Life in extreme ecosystems represent both eukaryotic and prokaryotic organisms, comparative analysis of all taxa in complex biocoenosis of each ecosystem will provide answers to the fundamental questions of the origin, distribution, and evolution of life (Pikuta et al. 2007). In contrast to the idea that extreme environments have relatively low biological diversity, our results support the hypothesis that contrasting conditions may actually promote phototrophic microbial diversity even in extreme environments. Our results were similar with other studies on phototrophic microbial communities from natural hypersaline environments, where the composition is limited to three taxonomic groups (i.e. chlorophytes, diatoms and cyanobacteria, Oren 2005). However, intermittent or intensive rains events may actually promote the colonization of several temporal species (Acc: accidental species, Table 2). On the contrary, the limited composition detected during the driest seasons appears to be the most successful adaptation to extreme hyper-arid conditions. The scatter in this 
relationship may in part be explained as an example of tolerance process from slightly brackish habitats to mesohaline or hypersaline ecotypes. Our results show that the structure and composition of phototrophic microbial communities from contrasting systems in the Salar de Alconcha were determined by different factors such as total salt concentration, conductivity, dissolved oxygen and ionic composition.

Salar de Alconcha is an highly variable active salar depending on the groundwater inputs in different zones, and thus, inflows water with very different salinities can coexist nearly. These conditions result in variable habitats with different forms of life (chlorophytes, cyanobacteria, and diatoms) existing at the edge of biological limit under extreme physiological conditions. Additionally, their natural conditions represent an exceptional opportunity to study microbial communities experiencing wide-range of environmental conditions. Our results suggest specific restrictive environments (e.g. environmental dissimilarity in the physical landscape) for phototrophic microbial colonization in active salars with variable saline systems (highly dependent upon water availability). Overall, these ecosystems represent fragile natural reservoirs under high pressure for groundwater associated to copper and others mineral extraction (intensive mining industry). Thus, technical biological support and habitat descriptions are essential for the efforts to preserve these unique ecosystems.

Acknowledgments This work was supported by CENIMA (Centro de Investigación de Medio Ambiente), UNAP institutional research project (IQUF03PRO-01020201007). The authors would like to express their sincere thanks to Walter Sielfeld Kowald for his assistance in collecting samples and his critical comments which helped to improve this manuscript.

\section{Compliance with ethical standards}

Conflict of interest The authors declare that they have no competing interests.

Author contribution AA formulated the hypothesis and designed the studies. AA and VH performed the sampling and analyses. AA and IV wrote the paper. All authors read and approved the final manuscript.

Open Access This article is distributed under the terms of the Creative Commons Attribution 4.0 International License (http:// creativecommons.org/licenses/by/4.0/), which permits unrestricted use, distribution, and reproduction in any medium, provided you give appropriate credit to the original author(s) and the source, provide a link to the Creative Commons license, and indicate if changes were made.

\section{References}

Alpers CN, Brimhall GH (1988) Middle Miocene climatic change in the Atacama Desert, northern Chile: evidence from supergene mineralization at La Escondida. Geol Soc Am Bull 100:1640-1656

APHA-AWWA-WEF (2005) Standard methods for the examination of water and wastewater, 21st edn. American Public Health Association, Washington DC

Arun N, Singh DP (2012) Microalgae: the future fuel (review). J Algal Biomass Utln 3(1):46-54

Avendaño V, Saíz F (1977) Taxocenosis de rotíferos limnéticos de la laguna El Plateado. Ans Mus Hist Nat Valparaíso 10:121-133

Azúa-Bustos A, Gonzales-Silva S, Salas L, Palma RE, Vicuña R (2010) A novel subaerial Dunaliella species growing on cave spiderwebs in the Atacama Desert. Extremophiles 14:443-452

Borowitzka MA, Huisman JM (1993) The ecology of Dunaliella salina (Chlorophyceae, Volvocales): effect of environmental conditions on aplanospore formation. Bot Mar 36:233-243

Cadima M, Fernandez E, Lopez L (2005) Algas de Bolivia con énfasis en el Fitoplancton: Importancia, Ecología, Aplicaciones y Distribución de Géneros. Centro de Ecología Difusión Simón I. Patiño, Santa Cruz

Clarke KR (1993) Non-parametric multivariate analysis of changes in community structure. Aust J Ecol 18:117-143

Demergasso C, Chong G, Galleguillos P, Escudero L, Martínez-Alonso M, Esteve I (2003) Microbial mats from the Llamará salt flat, northern Chile. Rev Chil Hist Nat 76:485-499

Demergasso C, Casamayor E, Chong G, Galleguillos P, Escudero L, Pedrós-Alió C (2004) Distribution of prokaryotic genetic diversity in athalassohaline lakes of the Atacama Desert, Northern Chile. FEMS Microbiol Ecol 48:57-69

Demergasso C, Escudero L, Casamayor EO, Chong G, Balagué V, Pedrós-Alió C (2008) Novelty and spatio-temporal heterogeneity in the bacterial diversity of hypersaline Lake Tebenquiche (Salar de Atacama). Extremophiles 4:491-504

Diaz C, Maidana N (2005) Diatomeas de los salares Atacama y Punta Negra II Region-Chile. Centro de Ecología Aplicada, Universidad de Chile

Dong J, Mao WH, Zhang GP, Wu FB, Cai Y (2007) Root excretion and plant tolerance to cadmium toxicity—a review. Plant Soil Environ 53(5): 193-200

Dorador C, Pardo R, Vila I (2003) Variaciones temporales de parámetros físicos, químicos y biológicos de un lago de altura: el caso del lago Chungara. Rev Chil Hist Nat 76:15-22 
Dorador C, Vila I, Imhoff JF, Witzel KP (2008) Cyanobacterial diversity in Salar de Huasco, a high altitude saline wetland in northern Chile: an example of geographical dispersion? FEMS Microbiol Ecol 64:419-432

Dorador C, Vila I, Remonsellez F, Imhoff JF, Witzel KP (2010) Unique clusters for Archaea in Salar de Huasco, an athalassohaline evaporitic basin of the Chilean Altiplano. FEMS Microbiol Ecol 73:291-302

Finke N, Hoehler TM, Polerecky L, Buehring B, Thamdrup B (2013) Competition for inorganic carbon between oxygen and anoxygen phototrophs in hypersaline microbial mats, Guerrero Negro, Mexico. Environ Microbiol 15(5):1532-1550

Fournier RO (1978) Membrane filtering. In: Sournia A (ed) Phytoplankton manual. Monographs on oceanographic methodology, vol 6. Unesco, Paris, pp 108-112

Gauch HG (1982) Multivariate analysis in community structure. Cambridge University Press, Cambridge

Germain H (1981) Flore des diatomées d'éau douces et saumatres. Société Nouvelle des Éditions Boubée, Paris

Ginzburg M (1987) Dunaliella: a green alga adapted to salt. Adv Bot Res 14:93-183

Hamburger C (1905) Zur Kenntnis der Dunaliella salina und einer Amöbe aus Salinenwasser von Cagliari. Arch Protistenkd 6:111-131

Harper D.A.T. (ed. 1999) Numerical Palaeobiology. John Wiley and Sons, New York

Iltis A, Risacher F, Servant S (1984) Contribution a l'etude hidrobiologique des lacs sales du sud de l' Altiplano bolivien. Rev Hydrobiol Trop 17:256-273

Jin ES, Feth B, Melis A (2003) A mutant of the green algae Dunaliella salina constitutively accumulates zeaxanthin under all growth conditions. Biotechnol Bioeng 81:115-124

Kunte H, Trüper H, Stan-Lotter H (2002) Halophilic microorganisms. In: Horneck G, Baumstark-Khan C (eds) Astrobiology, the quest for the conditions of life. Springer, Koln, pp 185-200

Lange B, Mary Ann T (2002) The diatom flora of the Salton Sea, California. Hydrobiologia 473:179-201

Leonardi PI, Cáceres EJ (1997) Light and electron microscope observations of the life cycle of Dunaliella salina (Polyblepharidaceae, Chlorophyceae). Nova Hedwigia 64:621-633

Maldonado F (2014) An introduction to the bofedales of the Peruvian high Andes. Mires Peat 15(5):1-13

Mancinelli R, Fahlen T, Landheim R, Klovstad M (2004) Brines and evaporates: analogs for Martian life. Adv Space Res 33:1244-1246

Margalef R (1983) Limnología. Omega, Barcelona

Margulis L, Barghoorn ES, Ashendorf D, Banerjee S, Chase D, Francis S, Giovanonni S, Stolz J (1980) The microbial community in layered sediments at Laguna Figueroa, Baja California, Mexico: does it have Precambrian analogues? Precambrian Res 11:93-123

Márquez-García M, Vila I, Hinojosa L, Mendez M, Carvajal J, Sabando M (2009) Distribution and seasonal fluctuations in the aquatic biodiversity of the southern Altiplano. Limnologica 39:314-318

Massyuk NP (1973) Morfologija, Sistematika, Ekologija, Geograficheskoe Rasprostranemie Roda Dunaliella Teodoresco. "Naukova Dumka", Kiev, pp 1-244

Oren A (2002) Molecular ecology of extremely halophilic Archaea and Bacteria. FEMS Microbiol Ecol 39:1-7

Oren A (2005) A hundred years of Dunaliella research: 1905-2005. Saline Syst 1:2

Oren A, Ben-Yosef N (1997) Development and spatial distribution of an algal bloom in the Dead Sea: a remote sensing study. Aquat Microb Ecol 13:219-223

Parsons TR, Maita Y, Lalli CM (1984) a manual of chemical and biological methods for sea water analysis. Pergamon, Elmsford

Pikuta EV, Hoover RB, Tang J (2007) Microbial extremophiles at the limits of life. Crit Rev Microbiol 33:183-209

Rasuk MC, Kurth D, Flores MR, Contreras M, Novoa F, Poire D, Farias ME (2014) Microbial characterization of microbial ecosystems associated to evaporites domes of gypsum in Salar de Llamara in Atacama Desert. Microb Ecol 68(3):483-494

Risacher F, Alonso H, Salazar C (2003) The origin of brines and salts in Chilean salars: a hydrochemical review. Earth-Sci Rev 63:249-293

Sabbe K, Verleyen E, Hodgson DA, Vanhoutte K, Vyverman W (2002) Benthic diatom flora of freshwater and saline lakes in the Larsemann Hills and Pauer islands, East Antarctica. Antarct Sci 15:227-248

Scott S, Dorador C, Oyanedel JP, Tobar I, Hengst M, Maya G, Harrod C, Vila I (2015) Microbial diversity and trophic components of two high altitude wetlands of the Chilean Altiplano. Gayana 79(1):45-56

Simonsen R (1987) Atlas and catalogue of the diatom Types of frederich Hustedt, J. Cramer. Gerbrüder Borntraeger, Berlin, Stuttgart

Teodoresco EC (1905) Organisation et développement du Dunaliella, nouveau genre de Volvocacée-Polyblepharidée. Beihz Bot Centralbl, Bd. XVIII, p 215-232

ter Braak CJF (1988) CANOCO—a FORTRAN program for canonical community ordination by [partial] [detrended] [canonical] correspondence analysis, principal 18 components analysis and redundancy analysis (version 2.1). Report LWA-88-02, Agricultural Mathematics Group, Wageningen

ter Braak CJF, Šmilauer P (1998) CANOCO reference manual and user's guide to Canoco for Windows: software for canonical community ordination (version 4) microcomputer power. Ithaca, New York, pp 352-353

Thiel V, Tank M, Neulinger SC, Gehrmann L, Dorador C, Imhoff JF (2010) Unique communities of anoxygenic phototrophic bacteria in saline lakes of Salar de Atacama (Chile): evidence for a new phylogenetic lineage of phototrophic Gammaproteobacteria from pufLM gene analyses. FEMS Microbiol Ecol 74:510-522

Utermöhl H (1958) Neue wege in der quantitativen erfassung des plankton (mit besonderer Berücksichtigung des Ultraplanktons). Ver Int Ver Theor Angew. Limnol 5:567-596

Vila I, Muhlhauser H (1987) Dinámica de lagos de altura. Perspectivas de investigación. Arch Biol Med Exp 20:95-103

Zúñiga LR, Campos V, Pinochet H, Prado B (1991) A limnological reconnaissance of lake Tebenquiche, Salar de Atacama, Chile. Hydrobiologia 210:19-24 